\title{
Problemy dysleksji, czyli specyficznych trudności w czytaniu - refleksje na kanwie lektury serii książek Anny Radwańskiej
}

Problems of dyslexia or specific reading difficulties - reflections based on book series written by Anna Radwańska

Słowa kluczowe: dysleksja, zaburzenia czytania i pisania, terapia pedagogiczna, glottodydaktyka Keywords: dyslexia, reading and writing disorders, pedagogical therapy, glottodidactics

\section{Wprowadzenie}

Problemy szkolne uczniów na początkowych szczeblach edukacji można analizować $\mathrm{z}$ wielu perspektyw. Jedną z najczęściej przyjmowanych w naszym kraju jest tzw. perspektywa dyslektyczna, uznająca za pewnik istnienie zjawiska dysleksji. Badacze reprezentujący ten punkt widzenia odwołują się do prac innych autorów, przez ukazanie historii badań nad dysleksją starają się dowieść, jak ważna jest przyjęta przez nich perspektywa i jak istotne jest jej podtrzymywanie. Tymczasem prawdziwe badanie naukowe ma sens tylko wtedy, gdy przedmiot badań - czyli w tym wypadku dysleksja - może być „rozebrany na czynniki pierwsze”, oceniony rygorystycznie, łącznie z możliwością zakwestionowania jego realności, metodologicznych podstaw i ustanowienia nowych paradygmatów badawczych.

Zacznijmy jednak od pytań: „Kto jako pierwszy podjął problematykę lokalizacji mózgowej trudności w czytaniu i pisaniu?”, „Skąd wzięło się zainteresowanie wynikami takich badań i ich praktycznym zastosowaniem?”.

\footnotetext{
* Uniwersytet Gdański, Wydział Filologiczny, Katedra Logopedii, ul. Bażyńskiego 8, 80-309 Gdańsk, e-mail: malgorzata.roclawska-daniluk@ug.edu.pl, https://orcid.org/0000-0002-7060-2934
} 


\section{Dysleksja z perspektywy historycznej}

Najdawniejszym zachowanym zapisem dotyczącym umiejscowienia rozmaitych funkcji w mózgu jest „papirus chirurgiczny” Edwina Smitha, pochodzący ze starożytnego Egiptu, datowany na lata 2500-3000 p.n.e. Jest on uważany za „najstarszy znany dokument naukowy" [Walsh, Darby, 2008, s. 13]. Jego tłumaczenie rozpoczęto dopiero w 1920 roku, podkreślając przy tym niezwykłą dokładność w przedstawianiu urazów różnych części ciała, w tym także głowy i mózgu.

Ustalając chronologię badań mających związek z dysleksją, można zauważyć, iż pierwsze obserwacje dotyczące tego zjawiska datowane są w dostępnych źródłach dopiero na wieki XVIII i XIX. To właśnie wtedy Franz Josef Gall i Johann Spurzheim prowadzili badania dotyczące neuronalnych podstaw różnych funkcji psychicznych. Gall jako pierwszy wskazał na istnienie związku funkcji językowych z rejonem płatów czołowych w mózgu, inspirując Jeana Baptiste’a Bouillauda oraz Paula Broca. Wnikliwe badania mózgów 25 zmarłych osób z objawami afazji zaowocowały koncepcją specjalizacji półkul mózgowych. Po wielu obserwacjach rejon w lewej półkuli mózgu, odpowiedzialny za generowanie mowy, nazwano ośrodkiem Broki, a jego uszkodzenie określono mianem afazji Broki [Robertson, 2001, s. 4]. Znamienny jest fakt, iż już u zarania badań dotyczących mózgowej lokalizacji funkcji językowych pojawiały się próby pseudonaukowych interpretacji zebranych przez Galla danych, dokonywane przez frenologów, którzy - na podstawie kształtu czaszek badanych ludzi - próbowali określać ich talenty i słabości. Kierowali się przeświadczeniem, iż lepiej rozwinięta funkcja psychiczna ma bardziej rozwinięte podłoże neuroanatomiczne, co można dostrzec, przyglądając się uwypukleniom czaszek badanych pacjentów.

Z grona badaczy, którzy zainteresowali się problematyką dysleksji lub inaczej „ślepoty słownej" (ang. congenital word-blindness), warto wyróżnić takich lekarzy, jak: okulista i jednocześnie autor określenia dysleksja Rudolf Berlin, psychiatra Antonin Heveroch, okulista James Hinshelwood oraz neurolog Samuel Torrey Orton. Ten ostatni w 1949 roku zainicjował powstanie w USA międzynarodowego towarzystwa, znanego pod nazwą Orton Society Dyslexia [Sovak, 1978] lub Towarzystwo Dysleksji im. Ortona [Radwańska, 2017, s. 11].

W Polsce wiedza na temat dysleksji - nazywanej pierwotnie na wzór niemiecki legastenią (niem. Legasthenie) - datowana jest na lata międzywojenne. W 1937 roku ukazała się popularnonaukowa broszura Reny Uzdańskiej pt. Trudności w nauce czytania $i$ pisania. Zawarte jest w niej wiele cennych spostrzeżeń dotyczących rodzajów błędów popełnianych w czytaniu przez dzieci, przyczyn występujących trudności, podstawowych metod diagnozy i terapii. Napisana pięknym, choć miejscami nieco już archaicznym językiem, niezwykle komunikatywna i zaskakująco aktualna, powinna nadal być czytana i twórczo wykorzystywana przez rodziców i nauczycieli.

W latach powojennych problematykę dysleksji w naukowy obieg w Polsce wprowadziła Anna Drath, specjalizująca się w psychiatrii dziecięcej. Opublikowała ona w 1959 roku 
w czasopiśmie „Szkoła Specjalna” artykuł pt. Dysleksja. Jak podaje Marta Bogdanowicz [2016, s. 100], dzięki Drath możliwe było rozpoczęcie terapii z uczniami z trudnościami szkolnymi. W kolejnych latach Drath nie podejmowała już problematyki dysleksji - uwagę skupiła na zagadnieniach dotyczących dzieci nerwicowych [Drath, 1986].

Jednak dopiero prace psycholog Haliny Spionek [1963; 1965] pozwoliły dostrzec w dysleksji pochodną zaburzeń percepcyjno-motorycznych. Szczególną wagę na tym etapie zainteresowania dysleksją przywiązywano do diagnozy zarówno dysleksji, jak i dysgrafii u dzieci, posiłkując się, z braku polskich norm, metodami normalizowanymi we Francji, autorstwa Miry Stambak, Hildy Santucci i René Zazzo. Ocena funkcji językowych w polskojęzycznej populacji była ze zrozumiałych względów bardzo utrudniona, prowadzona bez należytych narzędzi, jedynie na podstawie norm rozwojowych [Bogdanowicz, 2016, s. 100].

\section{Wydanie pierwszego podręcznika do terapii pedagogicznej w Polsce}

Nowy rozdział w terapii pedagogicznej w Polsce otworzył podręcznik Barbary Zakrzewskiej pt. Reedukacja dzieci z trudnościami w czytaniu i pisaniu (wyd. 1976). Opis tej publikacji znajdujemy w pracy Marty Bogdanowicz:

Książka jest pierwszym podręcznikiem w całości poświęconym pomocy uczniom z dysleksją. Zaprezentowano w niej zjawisko dysleksji i terapii pedagogicznej, zajęcia korekcyjno-kompensacyjne: sposób ich przeprowadzania, indywidualne podejście do każdego przypadku oraz specyficzne właściwości stosowanych metod. Modele ćwiczeń wraz z instrukcją (kształcące percepcję i pamięć wzrokową, słuchową, poziom graficzno-motoryczny pisma oraz orientację przestrzenną) stanowią gotowy materiał do pracy z dzieckiem [Bogdanowicz, 2005, s. 123].

Spod pióra Zakrzewskiej wyszło wiele książek adresowanych do przedszkolaków i uczniów szkoły podstawowej. Wśród nich jest pozycja pt. Trudności w czytaniu i pisaniu. Modele ćwiczeń, w której autorka opisała trzy skale oceny czytania i pisania, zainspirowane normami czeskimi i austriackimi, odpowiednio zmodyfikowanymi i wzbogaconymi. Jedną z nich jest skala dotycząca techniki czytania. Zgodnie z nią najniżej oceniane „czytanie” to właściwie pseudotechnika czytania [Rocławski, 2005]. Dziecko nieznające większości liter małych i dużych nie powinno jeszcze być oceniane ${ }^{1}$, gdyż sytuacja, w której ma za zadanie przeczytać wskazany tekst możliwie jak najlepiej, mogłaby być dla niego zbyt stresująca [Zakrzewska, 1999, s. 199].

1 Zakrzewska zasygnalizowała w przypisie potrzebę opracowania arkuszy ocen dla zaprezentowanych skal czytania i pisania. 
Autorka tego podręcznika w pierwszych zdaniach rozdziału poświęconego najważniejszym aspektom specyficznych trudności w czytaniu i pisaniu umieściła ważną deklarację:

\begin{abstract}
Omawianie najważniejszych teoretycznych aspektów problemu specyficznych trudności w czytaniu i pisaniu (dysleksji) rozpoczniemy od pojęcia prawidłowego czytania i pisania. Bez zrozumienia bowiem istoty umiejętności czytania i pisania nie można przystąpić do analizy ich anomalii i zaburzeń. Nie można też ich przezwyciężać i usuwać [Zakrzewska, 1999, s. 15].
\end{abstract}

Jednak bliższe przyjrzenie się zawartości podręcznika Zakrzewskiej prowadzi do wniosku, że autorka nie zrealizowała swojej wstępnej deklaracji. Poza kilkoma akapitami zawierającymi suche definicje i specjalistyczne określenia w bardzo niewielkim stopniu zdołała wyjaśnić, czym jest czytanie, a w porównaniu z przedwojenną broszurą Uzdańskiej znacznie oddaliła się od wyjaśnienia problematyki czytania. Optymizmem nie napawa także praktykowana przez autorkę zasada dwukrotnego czytania, która ma dawać dziecku poczucie sportowej rywalizacji i zachęcać do przyspieszania tempa, co niestety może przyczynić się do czytania bezrefleksyjnego, będącego w istocie jedynie dekodowaniem (odpoznawaniem) znaków graficznych.

\title{
Recenzja serii książek Anny Radwańskiej skierowanych do dzieci z dysleksją
}

Badania dotyczące dysleksji są intensywnie rozwijane w bardzo wielu ośrodkach w Polsce i za granicą. Ze względu na obszerność takiego zestawienia nie sposób wymienić nawet tych najważniejszych. Pewną orientację w tym zakresie można zyskać, zwracając uwagę na miejsca wydania nowych publikacji, takie jak Instytut Biologii Doświadczalnej im. M. Nenckiego PAN w Warszawie, David Fulton Publishers w Londynie czy Gdańskie Wydawnictwo Harmonia.

Wśród wielu różnorodnych podręczników oraz pozycji o charakterze poradnikowym, jakie ukazały się w ostatnich latach w Polsce, znajdują się trzy książki Anny Radwańskiej, opublikowane przez Wydawnictwo Difin². Serię rozpoczyna pozycja pt. Jak pomóc dziecku z dysleksją. Poradnik dla rodziców i nauczycieli. Zasadniczą częścią tej publikacji są „,ćwiczenia wspomagające naukę czytania i pisania” [Radwańska, 2017, s. 9], usystematyzowane według wieku dzieci, do których są skierowane. Kierując się deklaracją autorki, książka powinna być wyposażona w karty pracy - rodzaj pomocy dydaktycznej często wykorzystywanej w szkołach, a nawet w przedszkolach. Tym razem jednak czytelnik, zamiast nich, musi zadowolić się zbiorem ćwiczeń, z których może samodzielnie ułożyć karty pracy. Jest to niewątpliwie

2 Pełne adresy bibliograficzne znajdują się w literaturze na końcu artykułu. 
zgodne z intencją autorki, która wyraźnie zaznacza potrzebę indywidualizacji pracy terapeutycznej z każdym uczniem i być może celowo pozbawia czytelnika tzw. gotowców, skłaniając do poszukiwań odpowiednich materiałów w różnych miejscach poradnika.

Cały siódmy rozdział to bardzo zróżnicowane ćwiczenia - począwszy od wspomagających funkcje wzrokowe, przez ćwiczenia świadomości fonologicznej i pisania, a skończywszy na usprawniających czytanie. W środkowej części siódmego rozdziału znajdują się zasady poprawnej pisowni - niestety, niepozbawione błędów. Należy je więc czytać bardzo uważnie, uwzględnić potrzebę wprowadzenia poprawek na stronach 80-83, w odniesieniu do wyjątków od zasady pisowni „rz” po spółgłoskach (wyraz wszyscy nie należy do wyjątków, nie podpada bowiem pod regułę pisowni „rz" po spółgłosce /w/, gdyż wymawiamy go jako /fszyscy/), wymowy „ę" przed spółgłoską /k/ w wyrazie męka3, w odniesieniu do pisowni cząstki „chn” na stronie 160, którą trzeba zapisać inaczej w wyrazie druhna. Lista pomyłek w zasadach poprawnej pisowni jest dość duża, z konieczności ograniczam się jedynie do zasygnalizowania przykładowych błędów, które nie powinny znaleźć się w publikacji skierowanej do rodziców i nauczycieli.

Zdarzają się autorce także potknięcia świadczące o niedbałej redakcji tekstu, jak te w poniższych przykładach:

Dzieci dotkniętych dysleksją, ja wskazują badania, stanowi od 10-15\% wszystkich uczniów, więc każdy nauczyciel w swojej karierze zawodowej spotka się z takim zaburzeniem [...] [Radwańska, 2017, s. 11];

Pamiętaj, że dziecko dyslektyczne może uczyć się w nietypowy sposób, toteż nie należy go nie krytykować (np. ucząc się wiersza na pamięć, może skakać) [Radwańska, 2017, s. 55].

Niepokojące są także błędy w zadaniach skierowanych do uczniów - niektóre ilustracje są zbyt małe, aby można było rozpoznać, co się na nich znajduje (por. rycina na stronie 121), brakuje wyrazów, które uczeń ma odnaleźć w zadaniu (por. strony 140, 141), czy polecenia do ćwiczenia na stronie 109.

Obok tych wyraźnych niedociągnięć w poradniku znajdują się cenne wskazówki, jak na przykład:

Nie obniżaj wymagań edukacyjnych dzieciom dotkniętym dysleksją. Są to osoby z wysokim poziomem inteligencji, trzeba im specjalnych metod nauczania dostosowanych do ich potrzeb, a nie zmniejszania wymagań [Radwańska, 2017, s. 70].

3 Do celów edukacyjnych, aby uniknąć wymowy dwufonemowej /menka/, powinno się analizować z uczniami ten wyraz następująco: /m-ę-k-a/. 
W publikacji Radwańskiej na początku została przywołana definicja dysleksji z 1994 roku ${ }^{4}$. Ten słuszny metodologicznie krok miałby swoje uzasadnienie, gdyby autorka wraz z definicją podała sformułowane już przed dziesięcioma laty uwagi do tej definicji, opublikowane w artykule Marty Bogdanowicz [2009, s. 25-27] - skądinąd autorki recenzji wydawniczej omawianego poradnika.

Zdaniem Radwańskiej przyczyną specyficznych trudności w czytaniu i pisaniu jest nieharmonijny rozwój psychomotoryczny dziecka. Warto zauważyć, że są to trudności „specyficzne”, gdyż „występują od początku nauki u dzieci z normalnym poziomem inteligencji, lecz przy nieprawidłowym funkcjonowaniu układu nerwowego" [Radwańska, 2017, s. 12 - podkreślenie M.R.-D.]. W związku z tym wczesne rozpoznanie dysleksji jest zdaniem autorki bardzo ważne. Co więcej, należy pamiętać, aby dysleksji nie diagnozować u dzieci do końca III klasy szkoły podstawowej, ponieważ stopniowo opanowują one i doskonalą umiejętności czytania i pisania [Radwańska, 2017, s. 16]. Spośród nich można jedynie wyłonić grupę tzw. ryzyka dysleksji. W tym celu analizuje się odpowiedzi na 21 pytań skierowanych do opiekunów diagnozowanego dziecka, ustalając stopień zagrożenia dysleksją. Autorka publikuje w całości narzędzie diagnostyczne pt. Skala ryzyka dysleksji, przyczyniając się jednocześnie do jego popularyzacji.

Radwańska w wielu miejscach stosuje w swojej publikacji uproszczenia - wprowadza ważne jej zdaniem kwestie $\mathrm{w}$ formie wypisów $\mathrm{z}$ literatury, haseł lub podpunktów do pobieżnego przeczytania. Potencjalny odbiorca tego poradnika to najprawdopodobniej praktyk, poszukujący raczej materiałów do pracy z dziećmi niż wyjaśnień dotyczących tego, skąd bierze się dysleksja i czym się charakteryzuje. Najprawdopodobniej to założenie towarzyszyło autorce poradnika i może być przyczyną błędów w rozdziałach teoretycznych, takich jak zapisy świadczące o myleniu liter z głoskami na stronie 15 lub niejasne sformułowania dotyczące głosu fonemowego na stronie 17 .

W części ćwiczeniowej poradnika autorka propaguje czytanie sylabami lub całościowo (globalnie), niestety, nie wspominając techniki „ślizgania się”, czyli płynnego przechodzenia $\mathrm{z}$ głoski na głoskę lub z sylaby na sylabę, z powodzeniem stosowanej już od wielu lat w glottodydaktyce ojczystojęzycznej [Rocławska-Daniluk, 2018]. Słusznie zauważa, że głoskowanie nie powinno się długo utrzymywać, lecz nie wyjaśnia istoty problemu, nie wspomina o czytaniu płynnym, na sposób dorosłego

\footnotetext{
4 „Dysleksja jest jednym $\mathrm{z}$ wielu rodzajów trudności w uczeniu się. Jest specyficznym zaburzeniem o podłożu językowym, uwarunkowanym konstytucjonalnie. Charakteryzuje się trudnościami w dekodowaniu pojedynczych słów, co najczęściej odzwierciedla niewystarczające zdolności przetwarzania fonologicznego. Trudności w dekodowaniu pojedynczych słów są zazwyczaj niewspółmierne do wieku dziecka oraz innych zdolności poznawczych i umiejętności szkolnych: trudności nie są wynikiem ogólnego zaburzenia rozwoju ani zaburzeń sensorycznych. Dysleksja manifestuje się różnorodnymi trudnościami w odniesieniu do różnych form komunikacji językowej, często oprócz trudności w czytaniu (reading problems) pojawiają się poważne trudności w opanowaniu sprawności w zakresie czynności pisania (writing) i poprawnej pisowni (spelling)” [Radwańska, 2017, s. 11-12].
} 
czytelnika. W zamian za to tekst do czytania wyposaża w polecenia „Naucz się pięknie czytać!", proponując gdzieniegdzie czy tanie naprzemienne, które wypacza właściwy czytaniu rytm i powoduje, że dziecko nie chłonie samodzielnie treści, a raczej pilnuje kolejności czytania. Takie zabiegi mobilizują dzieci do kontaktu ze słowem pisanym, lecz nie rozwijają postawy indywidualnego skupienia na odkrywaniu treści, we własnym tempie i w wyznaczonym przez siebie celu.

Zastanawiające jest także przytoczone przez Radwańską stwierdzenie, jakoby dzieci z dysleksją posiadały „nieprawidłowe napięcie mięśniowe narządu mowy”, które może spowodować zmiany głosu w procesie czytania [Radwańska, 2017, s. 36]. Autorka nie podaje źródła tego poglądu, stąd można wnosić, że kieruje się własną obserwacją dzieci, z którymi pracowała nad usuwaniem zaburzeń czytania i pisania. Pogląd ten z pewnością należałoby poddać wnikliwej ocenie, gdyż sugerowane nieprawidłowości mogą mieć szersze konsekwencje dla dzieci z trudnościami w czytaniu i pisaniu, na przykład w postaci niechęci do słuchania swojego głosu lub mówienia w ogóle.

W drugiej książce z serii - Jak pomóc dziecku z dysleksja - wydanej w 2019 roku, Radwańska nie podaje w tytule, iż jej publikacja jest poradnikiem. W podtytule znajduje się jedynie informacja, że są to ćwiczenia dla uczniów klas IV-VI. Z niewiadomych przyczyn w tej części, w porównaniu do części pierwszej, całkowicie pominięto reguły poprawnej pisowni. Zamiast tego $\mathrm{z}$ całą mocą podkreślono, jak ważna jest praca korekcyjno-kompensacyjna oraz zaapelowano do rodziców, aby wspomagali nauczycieli i swoje dzieci w osiąganiu sukcesu edukacyjnego [Radwańska, 2019a, s. 176]. Część teoretyczna tej pozycji jest bardzo skromna, zawiera przedruki i krótkie analizy rozporządzenia Ministerstwa Edukacji Narodowej z 9 sierpnia 2017 roku, zdawkowe omówienia metod: dobrego startu, 18 struktur wyrazowych oraz 7 walizek. Nieco bardziej szczegółowo opisuje metody pracy z dziećmi z dysleksją na poszczególnych przedmiotach szkolnych.

Część praktyczna zawiera szereg ćwiczeń utrzymanych w podobnym stylu jak w pierwszej części poradnika.

W trzeciej publikacji z serii na pierwszy plan wybija się samoocena ucznia. Poradnik jest $\mathrm{z}$ jednej strony skierowany do uczniów klas VII i VIII szkoły podstawowej, o czym możemy przeczytać w rozdziale wstępnym, ale z drugiej strony podtytuł zawiera sformułowanie: „poradnik dla rodziców i nauczycieli”. Trudno więc stwierdzić, kto jest jego odbiorcą. Znajdziemy w nim dwa testy zaczerpnięte z publikacji Rickiego Linksmana [2005]: test na style uczenia się oraz test pozwalający ustalić dominującą półkulę mózgową. Wiele zastrzeżeń budzi rycina opublikowana na stronie 28 , przypominająca dwie półkule mózgowe, pozbawiona nazwy, za to pełna danych pochodzących z niewiadomego źródła. Są to dane o tyle interesujące, o ile można przypisać jakąś wartość powielanym w wielu publikacjach schematom odnoszącym się do specjalizacji pewnych obszarów naszych mózgów, a zapoczątkowanych już w czasach starożytnych. 
Pozostając jeszcze przez chwilę przy problematyce dotyczącej myślenia, natrafiamy na następujący fragment opublikowany w rozdziale Jak myśli uczeń z dysleksją?:

Myślenie: tematem myślenia mogą być: wydarzenia (obecne, zapamiętane, wyobrażone), rzeczy, problemy; odzwierciedla, analizuje i ocenia sytuacje; może dotyczyć teraźniejszości, przeszłości i przyszłości [Radwańska, 2019b, s. 29].

Z tym tematem wiąże się jeszcze jedna zaskakująca informacja, którą Radwańska zaczerpnęła z pozycji pt. Dar dysleksji. Dlaczego niektórzy zdolni ludzie nie umieja czytać i jak moga się nauczyć [Davis, Braun, 2001]. Według jej autorów obrazy w umyśle ucznia z dysleksją pojawiają się z prędkością 32 na sekundę. Radwańska stwierdza dodatkowo, iż „myślenie niewerbalne jest głębsze, całościowe, bardziej wyraziste, ewolucyjne" [Radwańska, 2019b, s. 30].

Część praktyczna zawiera duży zbiór tekstów do czytania, przedrukowanych $\mathrm{z}$ różnych źródeł, podanych $\mathrm{w}$ dwóch wersjach graficznych: ułatwiającej czytanie osobie z dysleksją oraz tradycyjnej, która według autorki stanowi duże utrudnienie dla uczniów z problemami w nauce czytania. Zagadnienie wielkości czcionki i jej kroju nie zostało omówione w części teoretycznej poradnika, toteż trudno dociec, skąd autorka czerpie prezentowane poglądy, czy zamierza poddać je rzetelnej, naukowej ocenie. Ponieważ jest doświadczonym praktykiem, ponownie można domniemywać, iż odwołuje się do osobistych obserwacji, co byłoby warte odnotowania i skomentowania, chociażby w przypisie. Ponadto w bibliografii brakuje pozycji, do których Radwańska odwołuje się w tekście, takich jak prace Barbary Arusztowicz, Leona Niebrzydowskiego czy Henryka Kulasa. Tego rodzaju niedociągnięć można było uniknąć na etapie dokładnej redakcji tekstu, której w tym wypadku zabrakło.

\section{Zakończenie}

Pomoc dziecku z dysleksją nie należy do łatwych zadań. Jest to najczęściej żmudny proces, wymagający zaangażowania wielu osób, a przede wszystkim zmotywowania do pracy samego dziecka. Tylko dobrze przygotowany nauczyciel podoła temu zadaniu, dobierze właściwe pomoce dydaktyczne, sięgnie po odpowiednie poradniki i właściwie wykorzysta zawartą w nich wiedzę.

W 1997 roku podczas międzynarodowej konferencji w Grecji, profesor Peter Pumfrey z Uniwersytetu w Manchesterze wypowiedział słowa, które pozostaną na zawsze w mojej pamięci: „Kulturowe i ekonomiczne zubożenie człowieka przeprowadza się na wiele sposobów, jednym $\mathrm{z}$ nich jest nazwanie go osobą z dysleksją (dyslektykiem)". Po wielu latach powracam do tego stwierdzenia, aby zadać pytanie o skutki niepodejmowania właściwych działań, które mogłyby uchronić dzieci przed dysleksją. 
Odpowiednie, możliwie zindywidualizowane podejście jest potrzebne każdemu dziecku, na każdym etapie dorastania do samodzielności. Niewystarczające zdolności przetwarzania fonologicznego można zminimalizować, rozwijając między innymi sprawności dzieci w zakresie syntez i analiz, o których wiele mówią wyniki obserwacji glottodydaktycznych [Rocławska-Daniluk, 2007; Harmacińska-Kowalewska, 2018].

Jestem zdania, iż nauczanie czytania i pisania, prowadzone w sposób w pełni przemyślany, może zapobiec wypaczeniom, jakie zawsze pojawiają się tam, gdzie brakuje rzetelności i wiedzy. Może także uciekać się do selekcjonowania dzieci, nadawania im nazw, umieszczania w specjalnych oddziałach. Takie dwie perspektywy są nadal obecne w teorii i praktyce terapeutycznej, stąd warto zadać sobie trud wnikliwej oceny każdej z nich.

Błędem jest podtrzymywanie perspektywy badawczej, zgodnie z którą poglądy na temat dysleksji są powielane w sposób bezkrytyczny. Jak można wnosić $\mathrm{z}$ przedstawionych tu analiz, w pracach poświęconych dysleksji da się znaleźć wiele kwestii wymagających dalszych szczegółowych badań, które warto konfrontować z możliwie szerokim kręgiem uczonych - nie tylko teoretyków, lecz także praktyków, borykających się z konkretnymi problemami szkolnymi swoich uczniów.

Literatura

Bogdanowicz M., 2009, Fakty, mity i kontrowersje wokół diagnozy dysleksji, [w:] G. Krasowicz-Kupis (red.), Diagnoza dysleksji. Najważniejsze problemy, Gdańsk: Wydawnictwo Harmonia, s. 16-39.

Bogdanowicz M. (red.), 2005, Terapia pedagogiczna. Przewodnik bibliograficzny, Gdańsk: Wydawnictwo Harmonia.

Bogdanowicz M. (red.), 2016, Dysleksja w wieku dorostym, Gdańsk: Harmonia Universalis.

Davis R.D., Braun E.M., 2001, Dar dysleksji. Dlaczego niektórzy zdolni ludzie nie umieja czytać i jak moga się nauczyć, Warszawa: Wydawnictwo Zysk i S-ka.

Drath A., 1959, Dysleksja, „Szkoła Specjalna”, nr 4-5, s. 194-201.

Drath A., 1986, Jak postępować z dzieckiem nerwicowym, Warszawa: Instytut Wydawniczy Związków Zawodowych.

Harmacińska-Kowalewska M., 2018, Pamięć dziecka a syntetyzowanie wyrazów z fonemów na etapie przygotowania do nauki czytania i pisania, niepublikowana rozprawa doktorska, Wydział Filologiczny Uniwersytetu Gdańskiego, promotor: M. Rocławska-Daniluk.

Linksman R., 2005, W jaki sposób szybko się uczyć, Warszawa: Świat Książki.

Radwańska A., 2017, Jak pomóc dziecku z dysleksją. Poradnik dla rodziców i nauczycieli, Warszawa: Wydawnictwo Difin.

Radwańska A., 2019a, Jak pomóc dziecku z dysleksją: ćwiczenia dla uczniów klas 4-6. Część 2, Warszawa: Wydawnictwo Difin.

Radwańska A., 2019b, Jak pomóc dziecku z dysleksją: poradnik dla rodziców i nauczycieli: ćwiczenia praktyczne dla uczniów 7-8 klas szkoły podstawowej. Część 3, Warszawa: Wydawnictwo Difin.

Robertson J., 2001, Dyslexia and Reading. A Neuropsychological Approach, London-Philadelphia: Whurr Publishers.

Rocławska-Daniluk M., 2007, Rozwój sprawności syntetyzowania wyrazów z fonemów w grupie dzieci 6-letnich, Gdańsk: Glottispol. 
Rocławska-Daniluk M., 2018, Czytanie i pisanie. Metodyka zajęć korekcyjno-wyrównawczych, Gdańsk: Wydawnictwo Uniwersytetu Gdańskiego.

Rocławski B., 2005, Badanie tempa i techniki czytania, Gdańsk: Glottispol.

Sovak M., 1978, Logopedie, Praha: Státni pedagogické nakladatelství.

Spionek H., 1963, Rozwój i wychowanie małego dziecka, Warszawa: Nasza Księgarnia.

Spionek H., 1965, Zaburzenia psychoruchowego rozwoju dziecka, Warszawa: Państwowe Wydawnictwo Naukowe.

Uzdańska R., 1937, Trudności w nauce czytania i pisania, http://pbc.gda.pl/dlibra/ doccontent?id=12405 (dostęp: 20.07.2019).

Walsh K., Darby D., 2008, Neuropsychologia kliniczna Walsha, Gdańsk: Gdańskie Wydawnictwo Psychologiczne.

Zakrzewska B., 1999, Trudności w czytaniu i pisaniu. Modele ćwiczeń, Warszawa: Wydawnictwa Szkolne i Pedagogiczne SA.

\section{Streszczenie}

Celem artykułu jest dokonanie przeglądu wybranej literatury dotyczącej dysleksji, opublikowanej w Polsce. Opis ukazuje perspektywę historyczną badań, a jego kulminacyjnym fragmentem jest recenzja serii opublikowanej w Wydawnictwie Difin przez Annę Radwańską w latach 2017-2019 pt. Jak pomóc dziecku $z$ dysleksją. Rozważania podsumowuje wskazanie dwóch perspektyw badawczych problematyki zaburzeń czytania i pisania, jakie rozwijane są obecnie w Polsce.

\section{Abstract}

The aim of the article is a review of selected literature on dyslexia published in Poland described from the historical perspective. The integral part of the review is devoted to the series Jakpomóc dziecku z dysleksja written by A. Radwańska and published by Difin in 2017-2019. This study has identified two scientific perspectives nowadays developed in Poland connected with reading and writing difficulties. 